\title{
Gonadotropin-releasing hormone 2 suppresses food intake in the zebrafish, Danio rerio
}

\author{
Ryo Nishiguchi ${ }^{1}$, Morio Azuma ${ }^{1}$, Eri Yokobori ${ }^{1}$, Minoru Uchiyama ${ }^{1}$ and Kouhei Matsuda ${ }^{1,2} *$ \\ ' Laboratory of Regulatory Biology, Graduate School of Science and Engineering, University of Toyama, Toyama, Japan \\ ${ }^{2}$ Laboratory of Regulatory Biology, Graduate School of Innovative Life Science, University of Toyama, Toyama, Japan
}

\section{Edited by:}

Hubert Vaudry, University of Rouen,

France

\section{Reviewed by:}

Jack Falcon, Université Pierre et Marie Curie and Centre National de la Recherche Scientifique, France John Chang, University of Alberta, Canada

\section{${ }^{*}$ Correspondence:}

Kouhei Matsuda, Laboratory of

Regulatory Biology, Graduate School of Science and Engineering,

University of Toyama, 3190 Gofuku, Toyama 930-8555, Japan.

e-mail:kmatsuda@sci.u-toyama.ac.jp
Gonadotropin-releasing hormone $(\mathrm{GnRH})$ is an evolutionarily conserved neuropeptide with 10 amino acid residues, of which several structural variants exist. A molecular form known as $\mathrm{GnRH} 2$ ([His $\left.{ }^{5} \mathrm{Trp}^{7} \mathrm{Tyr}^{8}\right] \mathrm{GnRH}$, also known as chicken $\mathrm{GnRH}$ II) is widely distributed in vertebrates except for rodents, and has recently been implicated in the regulation of feeding behavior in goldfish. However, the influence of $\mathrm{GnRH} 2$ on feeding behavior in other fish has not yet been studied. In the present study, therefore, we investigated the role of $\mathrm{GnRH} 2$ in the regulation of feeding behavior in a zebrafish model, and examined its involvement in food intake after intracerebroventricular (ICV) administration. ICV injection of $\mathrm{GnRH} 2$ at 0.1 and $1 \mathrm{pmol} / \mathrm{g}$ body weight (BW) induced a marked decrease of food consumption in a dose-dependent manner during $30 \mathrm{~min}$ after feeding. Cumulative food intake was significantly decreased by ICV injection of $\mathrm{GnRH} 2$ at $1 \mathrm{pmol} / \mathrm{g} \mathrm{BW}$ during the 30-min posttreatment observation period. The anorexigenic action of $\mathrm{GnRH} 2$ was completely blocked by treatment with the $\mathrm{GnRH}$ type I receptor antagonist Antide at $25 \mathrm{pmol} / \mathrm{g} \mathrm{BW}$. We also examined the effect of feeding condition on the expression level of the $\mathrm{GnRH} 2$ transcript in the hypothalamus. Levels of $\mathrm{GnRH} 2$ mRNA obtained from fish that had been provided excess food for 7 days were higher than those in fish that had been fed normally. These results suggest that, in zebrafish, $\mathrm{GnRH} 2$ acts as an anorexigenic factor, as is the case in goldfish.

Keywords: zebrafish, GnRH2, food intake, ICV administration, Antide, anorexigenic action

\section{INTRODUCTION}

Gonadotropin-releasing hormone $(\mathrm{GnRH})$ is an evolutionarily conserved decaneuropeptide that plays a crucial role in the regulation of reproduction in vertebrates (Sherwood etal., 1993; Fernald and White, 1999, Millar et al., 2004). The demonstration of GnRH structural variants in vertebrates, and even in invertebrates, has now resulted in the identification of 29 molecules (Guilgur et al., 2006; Kah et al., 2007; Roch et al., 2011). In vertebrates, these peptides are distributed in a wide range of tissues, and have diverse functions as hypophysiotropic hormones, paracrine or autocrine mediators and neuromodulators/neurotransmitters in the central and peripheral nervous systems and tissues (Gore, 2002; Millar, 2005; Kim et al., 2007; Millar et al., 2007). GnRH with substitutions at the N-terminal fifth, seventh, and eighth positions by histidine, tryptophan, and tyrosine residues, respectively, was originally purified and characterized as a second type of GnRH from chicken brain, and was named chicken GnRH II (now called GnRH2; Miyamoto et al., 1984). Subsequently, it has been found that $\mathrm{GnRH} 2$ is present throughout the vertebrates from cartilaginous fish to humans, but not in rodents (Conlon et al., 1993; Sherwood etal., 1993; White et al., 1998; Millar, 2003). GnRH2 has been implicated in the central regulation of reproductive behavior as well as neuroendocrine control of the gonads (Maney etal., 1997; Volkoff and Peter, 1999; Schiml and Rissman, 2000; White et al., 2002; Temple et al., 2003; Lethimonier et al., 2004; Hofmann, 2006). Recently, it has been reported that in an insectivore, the musk shrew, GnRH2 also influences feeding behavior, and that intracerebroventricular (ICV) administration of GnRH2 induces a marked decrease in food consumption, suggesting that GnRH2 controls reproduction and energy balance (Temple etal., 2003; Kauffman, 2004; Kauffman and Rissman, 2004a,b; Kauffman etal., 2005b, 2006). However, the involvement of GnRH in the regulation of feeding behavior had not been studied in other animal models.

Previous studies have indicated that ICV injection of GnRH2 also induces an anorexigenic effect in a goldfish model (Hoskins et al., 2008; Matsuda et al., 2008; Kang et al., 2011). In addition to goldfish, the zebrafish has now been widely used as an excellent animal model to investigate the effects of neuropeptides on feeding behavior (Yokobori et al., 2011, 2012; Matsuda et al., 2012). As in rodents and goldfish, it has been found that, in zebrafish, neuropeptide Y (NPY) and orexin A stimulate food intake (Yokobori et al., 2011, 2012; Matsuda et al., 2012). However, the exact role of GnRH2 is unclear, and there is no information about the effect of GnRH2 on feeding behavior in this species.

Therefore, the aim of the present study was to investigate the effect of GnRH2 on food intake in the zebrafish model, and the effect of ICV injection of Antide, a GnRH type I receptor antagonist, on the action of ICV-administered GnRH2. We also examined the effect of feeding condition on the expression level of the GnRH2 transcript in the hypothalamus. 


\section{MATERIALS AND METHODS}

\section{ANIMALS}

Adult zebrafish (Danio rerio, 0.5-1.0 g body weight, BW) of both sexes were obtained commercially, and kept for 2 weeks under controlled light/dark conditions (12 h light/12 h dark) in a water-temperature-regulated fish tank $\left(20-24^{\circ} \mathrm{C}\right)$ before use in experiments, since prevention of gonadal development. The fish were fed a commercially available granule diet (containing 32\% protein, $4 \%$ dietary fat, 3\% dietary fiber, $9 \%$ mineral, $8 \%$ water, and $44 \%$ other components; Hikari MariGold, Kyorin, Kobe, Japan) every day at noon. For 1 week before the experiments each fish was kept in a small experimental tank $(24 \mathrm{~cm}$ in diameter) with 3.51 of tap water. All animal experiments were conducted in accordance with the University of Toyama guidelines and the Declaration of Helsinki for the care and use of animals. Every effort was made to minimize the number of animals used and their suffering.

\section{CHEMICALS}

The zebrafish possesses two molecular forms of GnRH: GnRH2 (pGlu-His-Trp-Ser-His-Gly-Trp-Tyr-Pro-Gly-NH $\mathrm{NH}_{2}$ ), and GnRH3 (pGlu-His-Trp-Ser-Tyr-Gly-Trp-Leu-Pro-Gly- $\mathrm{NH}_{2}$; Powell et al., 1996; Steven et al., 2003). Therefore, in order to examine the effect of ICV injection of GnRH2 on food intake, GnRH2 was purchased from Bachem AG (Bubendorf, Switzerland) and used. Zebrafish possesses four kinds of GnRH receptors (GnRH R1-R4), GnRH $\mathrm{R} 1$ and R3 being of the GnRH type I receptor type whereas $\mathrm{GnRH}$ R2 and R4 are GnRH type III receptors (Tello et al., 2008). In the present study, we used the GnRH type I receptor antagonist, Antide (acetyl-D-Ala(2-naphthyl)-D-Phe(4-Cl)-D-Ala(3-pyridyl)Ser-Lys (N $\varepsilon$-nicotinoyl)-D-Lys ( $\mathrm{N} \varepsilon$-nicotinoyl)-Leu-Lys $(\mathrm{N} \varepsilon$-isopropyl)-Pro-D-Ala- $\mathrm{NH}_{2}$ ), obtained from Sigma-Aldrich Co. (St. Louis, MO, USA). Antide was dissolved in $0.1 \%$ acetic acid and diluted with $0.6 \% \mathrm{NaCl}$ and $0.02 \% \mathrm{Na}_{2} \mathrm{CO}_{3}$ solution (saline) before use.

\section{EFFECT OF ICV ADMINISTRATION OF GnRH2 ON FOOD INTAKE}

Details of the methods used for evaluating feeding behavior in zebrafish have been reported elsewhere (Yokobori et al., 2011, 2012). Each fish was normally fed before the experiments began at noon, and placed in a wet sponge under anesthesia with MS-222 (3-aminobenzoic acid ethyl ester; Sigma-Aldrich). A small part of the parietal bone was carefully removed using a surgical blade (No. 19, Futaba, Tokyo, Japan), and then $0.5 \mu \mathrm{l} / \mathrm{g}$ BW of GnRH2 at doses of 0.1 and $1 \mathrm{pmol} / \mathrm{g}$ BW was injected into the third ventricle of the brain using a small Hamilton syringe. The gap in the bone was then filled with a surgical agent (Aron Alpha, Sankyo, Japan). The accuracy of the injection site was confirmed after the experiment by examining whether Evans blue dye, injected at the same time, was present in the ventricle (Figure 1A). Control fish in each experiment were injected with the same volume of vehicle (less than $0.01 \%$ acetic acid diluted with saline) in the same way as for the experimental group. Each fish that had received an injection was individually placed in a small experimental tank (24 cm in diameter) containing 3.51 of tap water, and supplied with food equivalent to $3 \%$ of its BW. Food intake was measured by directly observing and recording the number of diet pellets
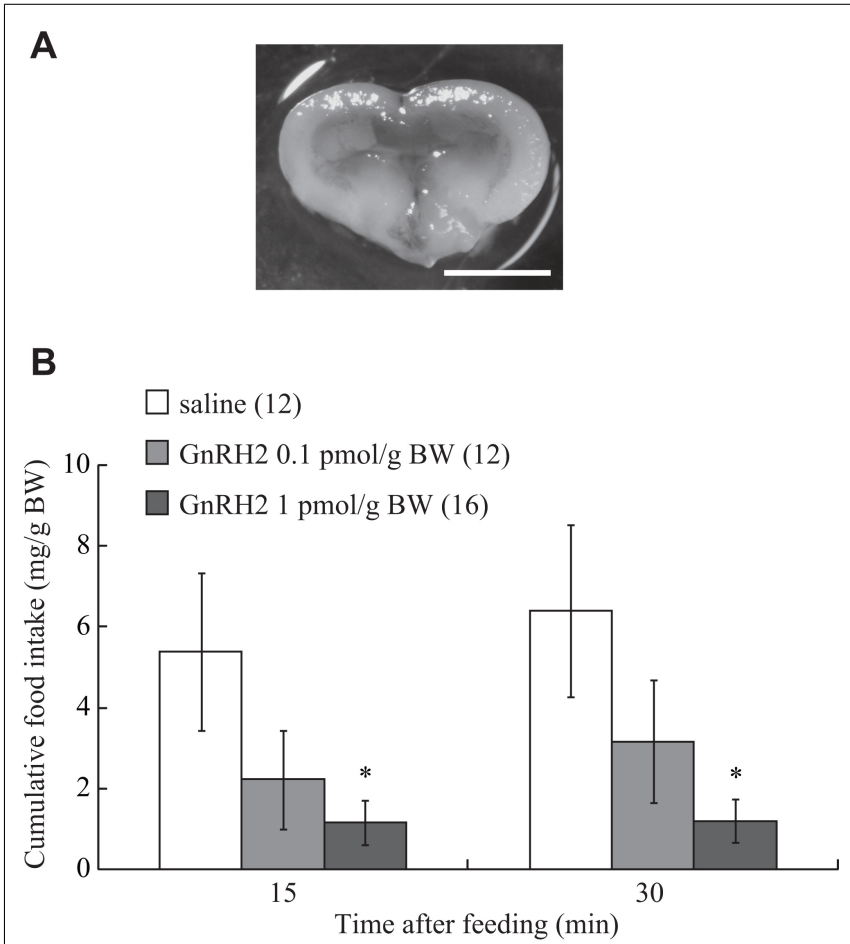

FIGURE 1 | (A) A photograph showing ICV administered-solution containing $0.05 \%$ Evans Blue into the brain. Scale bar is $1 \mathrm{~mm}$. (B) Effect of $\mathrm{ICV}$ administration of $\mathrm{GnRH} 2$ on food intake in the zebrafish. Each column and bar represents the mean and SEM, respectively, and the numbers in parentheses in the panels indicate the number of fish in each group. Significances of differences at each time point were evaluated by one-way ANOVA with the Bonferroni's method in comparison with the vehicleinjected group ( $\left.{ }^{*} P<0.01\right)$

eaten by individual fish over 15 and $30 \mathrm{~min}$ of commencement of feeding.

\section{EFFECT OF ICV INJECTION OF ANTIDE ON GnRH2-INDUCED ANOREXIGENIC ACTION}

Because pilot experiments had shown that ICV injection of cGnRH2 at a dose of $1 \mathrm{pmol} / \mathrm{g}$ BW induced a marked decrease of food intake, Antide at $25 \mathrm{pmol} / \mathrm{g} \mathrm{BW}$, a dose previously determined to be sufficient to suppress the action of GnRH2 in goldfish (Matsuda et al., 2008), was delivered by ICV injection in addition to $\mathrm{GnRH} 2$ at $1 \mathrm{pmol} / \mathrm{g}$ BW. Control fish were injected with the same volume of vehicle (less than $0.01 \%$ acetic acid diluted with saline) in the same way as for the experimental group. Food intake was then measured over the first 15 and 30 min of commencement of feeding, as described above.

\section{EFFECT OF FEEDING CONDITION ON GnRH2 mRNA EXPRESSION IN THE HYPOTHALAMUS}

Every day for 7 days, fish were supplied an excessive amount of food corresponding to $9 \%$ of their BW. Other fish were fed an amount of food corresponding to $3 \%$ of their BW for the same period. On day 7, the fish were anesthetized with MS222 and decapitated. Because the zebrafish brain is very small, 
each brain was dissected out, and the hypothalamus was collected, weighed, and immersed immediately in liquid nitrogen, before being stored at $-80^{\circ} \mathrm{C}$ until use. Total RNA was extracted from each part of the brain with Isogen (a solution containing phenol and guanidinium isothiocyanate; Nippon Gene, Tokyo, Japan). For amplification and quantitation of the cDNA fragments encoding GnRH2 and $\beta$-actin, the one-step reverse transcription polymerase chain reaction (RT-PCR) method (SYBR Green RTPCR Reagents Kit, Applied Biosystems, Foster City, CA, USA) was used. Reactions (including $5 \mu \mathrm{M}$ primers, $2 \times$ SYBR Green PCR master mix, 6.25 U MultiScribe reverse transcriptase, $10 \mathrm{U}$ RNase inhibitor, RNA template, and water) were set up in a 96well reaction plate and placed in a sequence detection system for cycling (TP 800, Takara, Tokyo, Japan). Reverse transcription was carried out at $48^{\circ} \mathrm{C}$ for $30 \mathrm{~min}$ and the resulting cDNA was subsequently amplified using 40 cycles of $95^{\circ} \mathrm{C}$ for $15 \mathrm{~s}$ followed by $60^{\circ} \mathrm{C}$ for $60 \mathrm{~s}$. The PCR products from each cycle were monitored using SYBR Green I fluorescent dye (Applied Biosystems). Gene-specific primers for amplification of the GnRH2 cDNA fragment were based on the nucleotide sequence of zebrafish GnRH2 (GenBank ID, BC162945.1, NM_181439; Ensembl ID, ENSDARG00000044754). PCR with the sense primer (5'-CAA AAT ATT AGA CTG AAG TGA TGG T-3') and the antisense primer (5'-GGT CTA TCT CTC TCT TTC CTC CA-3') yielded a 86-bp product encoding zebrafish GnRH2 cDNA. Zebrafish $\beta$ actin-specific primers were used as the internal control for PCR amplification (GenBank accession number, NM_181601; Ensembl ID, ENSDART00000055194). Using these primers (sense primer, 5'-GTG ATG GAC TCT GGT GAT GGT GT-3'; antisense primer, 5'-TGA AGC TGT AGC CTC TCT CGG TC-3'), a 148-bp product corresponding to a region in the central part of the $\beta$-actin cDNA sequence was obtained. The expression levels of GnRH2 mRNA were calculated quantitatively as a ratio relative to the expression of $\beta$-actin mRNA.

\section{DATA ANALYSIS}

All the results are expressed as mean \pm SEM. Statistical analysis was performed by one- and two-way ANOVA with Bonferroni's method or Student's $t$-test. Statistical significance was determined at the $5 \%$ level.

\section{RESULTS}

\section{EFFECT OF ICV ADMINISTRATION OF GnRH2 ON FOOD INTAKE}

Intracerebroventricular injection of GnRH2 (at 0.1 and $1 \mathrm{pmol} / \mathrm{g}$ BW) inhibited food intake over a 30-min feeding period. A significant reduction in cumulative food consumption was observed at a dose of $1 \mathrm{pmol} / \mathrm{g} \mathrm{BW}$ at both 15 and $30 \mathrm{~min}$ after commencement of feeding (Figure 1B). The $d f, F$, and $P$ values between treatments with saline and GnRH2 were: 2, 3.08, and 0.06 at $15 \mathrm{~min} ; 2,3.51$, and 0.04 at $30 \mathrm{~min}$.

\section{EFFECT OF ICV INJECTION OF ANTIDE ON ANOREXIGENIC ACTION OF GnRH2}

Intracerebroventricular administration of $\mathrm{GnRH} 2$ alone at $1 \mathrm{pmol} / \mathrm{g}$ BW suppressed food intake over a 30-min feeding period, and ICV-injected Antide alone at $25 \mathrm{pmol} / \mathrm{g}$ BW did not affect food intake. On the other hand, the same dose of Antide completely

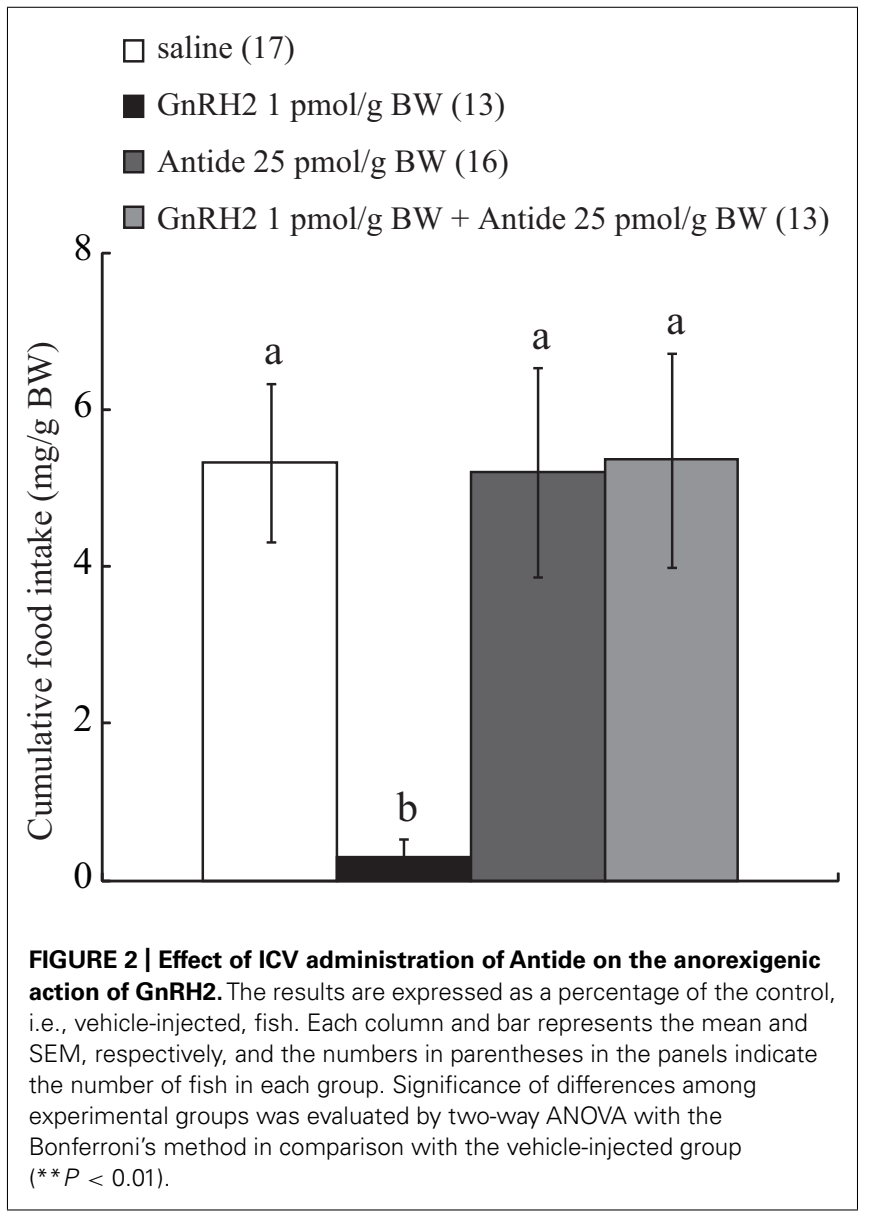

abolished the anorexigenic action of ICV-injected GnRH2 at a dose of $1 \mathrm{pmol} / \mathrm{g} \mathrm{BW}$, and the efficacy of the antagonist was shown to be significant by two-way ANOVA with Bonferroni's method ( $d f, F$, and $P$ values, 1, 4.39, and 0.04, respectively; Figure 2).

\section{EFFECT OF FEEDING CONDITION ON GnRH2 mRNA EXPRESSION IN THE HYPOTHALAMUS}

Figure 3 shows the expression levels of GnRH2 mRNA in the hypothalamus of zebrafish supplied an excessive amount of food corresponding to $9 \%$ of their BW, and normal amount of food corresponding to $3 \%$ of their BW. Expression of GnRH2 mRNA was estimated quantitatively as a ratio relative to the expression of $\beta$-actin mRNA. In the hypothalamus, excessive feeding for 7 days induced a significant increase (approximately four times higher) in the level of GnRH2 mRNA compared with that in fish that had been fed normally ( $t$ and $P$ values, 2.82 and 0.012 , respectively; Figure 3).

\section{DISCUSSION}

We have developed methods for administering ICV test substances and for measuring food consumption in a small fish, the zebrafish, and our previous studies have demonstrated that, in this species, NPY and orexin A act as orexigenic neuropeptides (Yokobori et al., 2011, 2012). In the present study, we investigated the effect of central administration of $\mathrm{GnRH} 2$ on food 


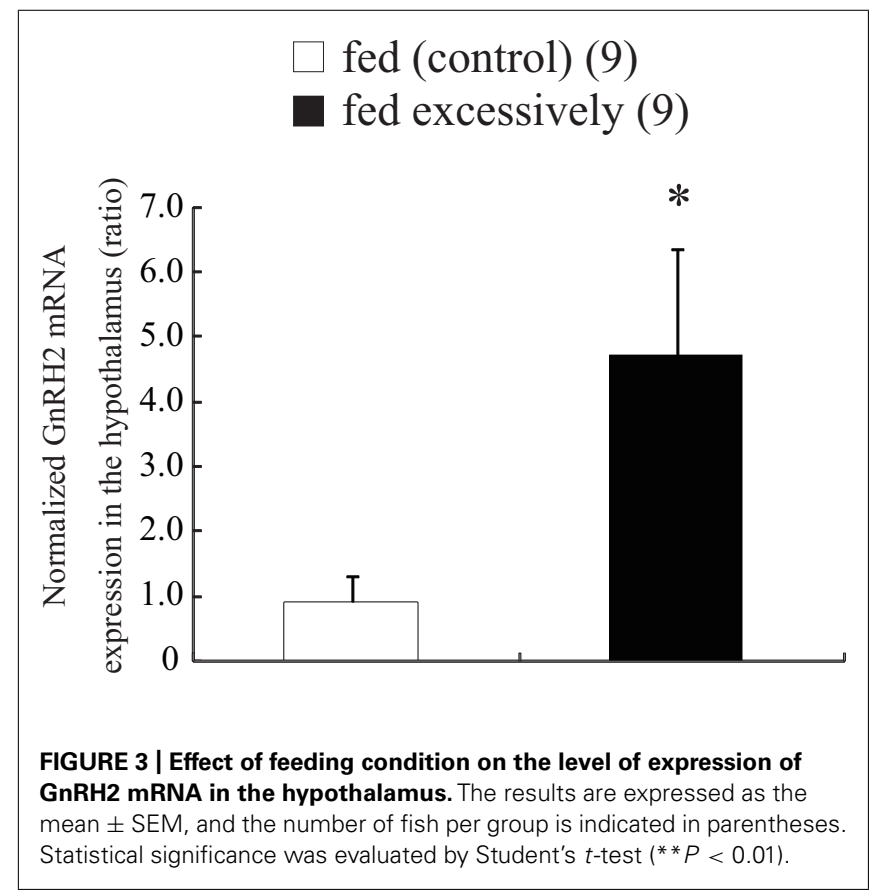

intake, and demonstrated for the first time that GnRH2 strongly suppresses food consumption in the zebrafish. In matured female musk shrew, an insectivore, ICV injection of GnRH2 inhibits food intake, and feeding status influences the levels of both GnRH2 mRNA expression and immunoassayable GnRH2 in the brain, which are decreased by food restriction (Kauffman and Rissman, 2004a; Kauffman et al., 2006). The present study indicates the anorexigenic action of $\mathrm{GnRH} 2$ in the zebrafish, as is the case in female musk shrew and goldfish (Hoskins et al., 2008; Matsuda etal., 2008; Kang etal., 2011), indicating that it may be involved generally in the regulation of feeding behavior in vertebrates. GnRH3 is widely distributed in several regions of the zebrafish brain, including the olfactory bulb, the area of the terminal nerve, and telencephalon, and GnRH3 is implicated in pituitary control (Torgersen et al., 2002; Steven et al., 2003; Palevitch et al., 2007). On the other hand, GnRH2-expressing neurons are localized mainly in the midbrain tegmentum (Palevitch et al., 2007). However, the exact role of GnRH2 in the zebrafish has been unclear. Because GnRH2 is implicated in the regulation of reproductive behavior and energy balance in the female musk shrew, sparrow, and goldfish (Maney et al., 1997; Temple et al., 2003; Kauffman, 2004; Kauffman and Rissman, 2004a; Kauffman et al., 2005a,b; Hofmann, 2006; Hoskins et al., 2008; Matsuda et al., 2008; Kang et al., 2011), it is likely that, in zebrafish, GnRH2 is involved in both feeding control and reproductive behavior. GnRH systems have been well studied in teleost fish (Lethimonier et al., 2004). The zebrafish possesses two GnRHs - GnRH2 and GnRH3 - which are encoded by two distinct genes (Steven et al., 2003), and four GnRH receptors, GnRH R1-R4 - which are members of the $\mathrm{G}$ protein-coupled receptor family (Tello et al., 2008). There are marked differences in structure between these two groups of GnRHRs. GnRH R1 and R3 are evolutionarily derived from the common ancestor of the GnRH type I receptor, and GnRH R2 and R4 belong to the GnRH type III receptor group (Tello et al., 2008). In the present study, ICV administration of GnRH2 at $1 \mathrm{pmol} / \mathrm{g}$ BW induced a significant decrease of food intake, and this effect was completely blocked by treatment with Antide. Antide is the GnRH type I receptor antagonist (Kauffman et al., 2005b; Matsuda et al., 2008). These results suggest that the anorexigenic action of $\mathrm{GnRH} 2$ is mediated by the Antide-sensitive receptor system, perhaps involving GnRH R1 and/or R3. The knowledge about the expression and the distribution of GnRH receptors in the zebrafish brain should help us to speculate on the mechanisms underlying GnRH2-induced anorexigenic effect. However, there has been no information about distribution of $\mathrm{GnRH}$ receptors in the hypothalamus. It is unclear which receptor type mediates the anorexigenic action of $\mathrm{GnRH} 2$ in zebrafish.

In mammals, several neuropeptides including $\mathrm{CRH}$, galaninlike peptide, LHRH (GnRH1), kisspeptin, $\alpha-M S H, N P Y$, orexin, and $26 \mathrm{RFa}$ are implicated in the regulation of nutrition and reproduction, suggesting that feeding and reproductive functions are closely linked (Catzeflis et al., 1993; Iqubal et al., 2001; Chartrel et al., 2003; Kauffman et al., 2005a; Crown et al., 2006; Martynska et al., 2006; Navarro et al., 2006; Maeda et al., 2007). Orexin, which has crucial role in the sleep-wakefulness cycle and appetite control, affects GnRH1 release directly or via the NPY-, CRH-, and $\beta$ endorphin-signaling pathways (Li et al., 1999; Tamura et al., 1999; Irahara et al., 2001; Yang et al., 2005; Iwasa et al., 2007). In goldfish, ICV administration of orexin A suppresses spawning behavior, and ICV administration of GnRH2 reduces the level of orexin precursor mRNA in the brain (Hoskins et al., 2008). These data suggest that, in goldfish, GnRH2 and orexin have opposite roles in appetite and satiety regulation. Our previous studies have revealed that mRNA expression levels for NPY and orexin in the hypothalamus obtained from zebrafish fasted for 7 days are higher than those in zebrafish that had been fed normally, suggesting NPY and orexin in the hypothalamus act as orexigenic factors in this species. In the present study of zebrafish, we focused on the GnRH2 neuronal system, which has been implicated in the regulation of food intake in the goldfish (Matsuda et al., 2008), and demonstrated for the first time that the expression of GnRH2 mRNA in the hypothalamus is affected by feeding status. The results support the idea that GnRH2 in the hypothalamus acts as an anorexigenic neuropeptide in this species. Further investigations to clarify the regulatory mechanism of food intake by $\mathrm{GnRH} 2$ and other neuropeptides and factors are warranted.

In conclusion, the present study has demonstrated for the first time that ICV administration of GnRH2 suppresses food intake in the zebrafish. These results suggest that GnRH2 induces behavioral changes, and in particular acts as an anorexigenic factor in this species. The present findings also indicate that evolutionary pressure has acted to preserve the function of $\mathrm{GnRH} 2$ as a feeding regulator across the vertebrates.

\section{ACKNOWLEDGMENTS}

This work was supported by a Grant-in-Aid from the Japan Society for Promotion of Science (21370025 to Kouhei Matsuda), and by a research grant from the University of Toyama (to Kouhei Matsuda). 


\section{REFERENCES}

Catzeflis, C., Pierroz, D. D., RohnerJeanrenaud, F., Rivier, J. E., Sizonenko, P. C., and Aubert, M. L. (1993). Neuropeptide Y administered chronically into the lateral ventricle profoundly inhibits both the gonadotropic and the somatotropic axis in intact adult female rats. Endocrinology 132, 224-234.

Chartrel, N., Dujardin, C., Anouar, Y., Leprince, J., Decker, A., Clerens, S., et al. (2003). Identification of 26RFa, a hypothalamic neuropeptide of the RFamide peptide family with orexigenic activity. Proc. Natl. Acad. Sci. U.S.A. 100, 1524715252.

Conlon, J. M., Collin, F., Chiang, Y. C., Sower, S. A., and Vaudry, H. (1993). Two molecular forms of gonadotropin-releasing hormone from the brain of the frog, Rana ridibunda. Purification, characterization and distribution. Endocrinology 132, 2117-2123.

Crown, A., Clifton, D. K., and Steiner, R. A. (2006). Neuropeptide signaling in the integration of metabolism and reproduction. Neuroendocrinology 86, 175-182.

Fernald, R. D., and White, R. B. (1999). Gonadotropin-releasing hormone genes: phylogeny, structure, and functions. Front. Neuroendocrinol. 20, 224-240.

Gore, A. C. (2002). GnRH: The Master Molecule of Reproduction. Berlin: Springer.

Guilgur, L. G., Moncaut, N. P., Canario, A. V. M., and Somoza, G. M. (2006). Evolution of $\mathrm{GnRH}$ ligands and receptors in gnathostomata. Comp. Biochem. Physiol. A Mol. Integr. Physiol. 144, 272-283.

Hofmann, H. A. (2006). Gonadotropinreleasing hormone signaling in behavioral plasticity. Curr. Opin. Neurobiol. 16, 343-350.

Hoskins, L. J., $\mathrm{Xu}, \mathrm{M}$., and Volkoff, H. (2008). Interactions between gonadotropin-releasing hormone $(\mathrm{GnRH})$ and orexin in the regulation of feeding and reproduction in goldfish (Carassius auratus). Horm. Behav. 54, 379-385.

Iqubal, J., Pompolo, S., Sakurai, T., and Clarke, I. J. (2001). Evidence that orexin-containing neurons provide direct input to gonadotropinreleasing hormone neurons in the ovine hypothalamus. J. Neuroendocrinol. 13, 1033-1041.

Irahara, M., Tamura, T., Matsuzaki, T., Saito, S., Yasui, T., Yamano, S., etal. (2001). Orexin-A suppresses the pulsatile secretion of luteinizing hormone via $\beta$-endorphin. Biochem.
Biophys. Res. Commun. 281, 232-236.

Iwasa, T., Matsuzaki, T., Kiyokawa, M. Shimizu, F., Minakuchi, M., Kuwahara, A., etal. (2007). The type 2 corticotrophin-releasing hormone receptor mediates orexin A-induced luteinising hormone suppression in ovariectomised rats. J. Neuroendocrinol. 19, 732-738.

Kah, O., Lethimonier, C., Somoza, G. Guilgur, L. G., Vaillant, C., and Lareyre, J. J. (2007). GnRH and GnRH receptors in metazoa: a historical, comparative, and evolutive perspective. Gen. Comp. Endocrinol. 153, 346-364.

Kang, K. S., Shimizu, K., Azuma, M., Ui, Y., Nakamura, K., Uchiyama, M., etal. (2011). Gonadotropinreleasing hormone II (GnRH II) mediates the anorexigenic actions of $\alpha$-melanocyte-stimulating hormone $(\alpha-\mathrm{MSH})$ and corticotropinreleasing hormone $(\mathrm{CRH})$ in goldfish. Peptides 32, 31-35.

Kauffman, A. S. (2004). Emerging functions of gonadotropin-releasing hormone II in mammalian physiology and behaviour. J. Neuroendocrinol. 16, 794-806.

Kauffman, A. S., Bojkowska, K., Wills, A., and Rissman, E. F. (2006) Gonadotropin-releasing hormone-II messenger ribonucleic acid and protein content in the mammalian brain are modulated by food intake. Endocrinology 147, 5069-5077.

Kauffman, A. S., Buenzle, J., Fraley, G. S., and Rissman, E. F. (2005a). Effects of galanin-like peptide (GALP) on locomotion, reproduction, and body weight in female and male mice. Horm. Behav. 48, 141-151.

Kauffman, A. S., Wills, A., Millar, R. P., and Rissman, E. F. (2005b). Evidence that the type-2 gonadotrophinreleasing hormone $(\mathrm{GnRH})$ receptor mediates the behavioural effects of GnRH-II on feeding and reproduction in musk shrews. J. Neuroendocrinol. 17, 489-497.

Kauffman, A. S., and Rissman, E. F (2004a). A critical role for the evolutionarily conserved gonadotropinreleasing hormone II: mediation of energy status and female sexual behavior. Endocrinology 145 3639-3646.

Kauffman, A. S., and Rissman, E. F. (2004b). The evolutionarily conserved gonadotropin-releasing hormone II modifies food intake. Endocrinology 145, 686-691.

Kim, H. H., Mui, K. L., Nikrodhanond, A. A., and Tamayo, N. C. R. (2007). Regulation of gonadotropin-releasing hormone in nonhypothalamic tissues. Semin. Reprod. Med. 25, 326-336.

Lethimonier, C., Madigou, T., MunozCueto, J. A., Lareyre, J. J., and Kah, O. (2004). Evolutionary aspects of GnRH, GnRH neuronal systems and GnRH receptors in teleost fish. Gen. Comp. Endocrinol. 135, 1-16.

Li, C., Chen, P., and Smith, M. S. (1999). Morphological evidence for direct interaction between arcuate nucleus neuropeptide Y (NPY) neurons and gonadotropin-releasing hormone neurons and the possible involvement of NPY Y1 receptors. Endocrinology 140, 5382-5390.

Maeda, K., Adachi, S., Inoue, K., Ohkura, S., and Tsukamura, H. (2007). Metastin/kisspeptin and control of estrous cycle in rats. Rev. Endocr. Metab. Disord. 8, 21-29.

Maney, D. L., Richardson, R. D., and Wingfield, J. C. (1997). Central administration of chicken gonadotropin-releasing hormone-II enhances courtship behavior in a female sparrow. Horm. Behav. 32, 11-18.

Martynska, L., Polkowska, J., WolinskaWitort, E., Chmielowska, M. Wasilewska-Dziubinska, E., Bik, W., et al. (2006). Orexin A and its role in the regulation of the hypothalamopituitary axes in the rat. Reprod. Biol. 6, 29-35.

Matsuda, K., Azuma, M., and Kang, K. S. (2012). Effects of orexin on emotional and feeding behaviors in teleost fish. Vitam. Horm. 89, 341-361

Matsuda, K., Nakamura, K., Shimakura, S. I., Miura, T., Kageyama, H., Uchiyama, M., et al. (2008). Inhibitory effect of chicken gonadotropinreleasing hormone II on food intake in the goldfish, Carassius auratus. Horm. Behav. 54, 83-89.

Millar, R. P. (2003). GnRH II and type II GnRH receptors. Trends Endocrinol. Metab. 14, 35-43.

Millar, R. P. (2005). GnRHs and GnRH receptors. Anim. Reprod. Sci. 88, 5-28.

Millar, R. P., Lu, Z. L., Pawson, A. J., Flanagan, C. A., Morgan, K., and Maudsley, S. R. (2004). Gonadotropin-releasing hormone receptors. Endocr. Rev. 25, 235-275.

Millar, R. P., Pawson, A. J., Morgan, K., Rissman, E. F., and Lu, Z. L. (2007) Diversity of actions of GnRHs mediated by ligand-induced selective signaling. Front. Neuroendocrinol. 29, 17-35.

Miyamoto, K., Hasegawa, Y., Nomura, M., Igarashi, M., Kangawa, K., and Matsuo, H. (1984). Identification of the second gonadotropin-releasing hormone in chicken hypothalamus: evidence that gonadotropin secretion is probably controlled by two distinct gonadotropin-releasing hormones in avian species. Proc. Natl. Acad. Sci. U.S.A. 81, 3874-3878.

Navarro, V. M., Fernández-Fernandez, R., Nogueiras, R., Vigo, E., Tovar, S., Chartrel, N., et al. (2006). Novel role of $26 \mathrm{RFa}$, a hypothalamic RFamide orexigenic peptide, as putative regulator of the gonadotropic axis. $J$. Physiol. 573, 237-249.

Palevitch, O., Kight, K., Abraham, E., Wray, S., Zohar, Y., and Gothilf, Y. (2007). Ontogeny of the GnRH systems in zebrafish brain: in situ hybridization and promoter-reporter expression analyses in intact animals. Cell Tissue Res. 327, 313-322.

Powell, J. F., Krueckl, S. L., Collins, P. M., and Sherwood, N. M. (1996). Molecular forms of GnRH in three model fishes: rockfish, medaka and zebrafish. J. Endocrinol. 150, 17-23.

Roch, G. J., Busby, E. R., and Sherwood, N. M. (2011). Evolution of GnRH: diving deeper. Gen. Comp. Endocrinol. 171, 1-16.

Schiml, P. A., and Rissman, E. F. (2000). Effects of gonadotropinreleasing hormones, corticotropinreleasing hormone, and vasopressin on female sexual behavior. Horm. Behav. 37, 212-220.

Sherwood, N. M., Lovejoy, D. A., and Coe, I. R. (1993). Origin of mammalian gonadotropin-releasing hormones. Endocr. Rev. 14, 241-254.

Steven, C., Lehnen, N., Kight, K., Ijiri, S., Klenke, U., Harris, W. A., et al. (2003). Molecular characterization of the GnRH system in zebrafish (Danio rerio): cloning of chicken GnRH-II, adult brain expression patterns and pituitary content of salmon GnRH and chicken GnRHII. Gen. Comp. Endocrinol. 133, 27-37.

Tamura, T., Irahara, M., Tezuka, M., Kiyokawa, M., and Aono, T. (1999). Orexins, orexigenic hypothalamic neuropeptides, suppress the pulsatile secretion of luteinizing hormone in ovariectomized female rats. Bichem. Biophys. Res. Commun. 264, 759-762.

Tello, J. A., Wu, S., Rivier, J. E., and Sherwood, N. M. (2008). Four functional GnRH receptors in zebrafish: analysis of structure, signaling, synteny and phylogeny. Integr. Comp. Biol. 48, 570-587.

Temple, J. L., Millar, R. P., and Rissman, E. F. (2003). An evolutionarily conserved form of gonadotropinreleasing hormone coordinates energy and reproductive behavior. Endocrinology 144, 13-19. 
Torgersen, J., Nourizadeh-Lillabadi, R., Husebye, H., and Aleström, P. (2002). In silico and in situ characterization of the zebrafish (Danio rerio) gnrh3 (sGnRH) gene. $B M C$ Genomics 3, 25. doi: 10.1186/14712164-3-25

Volkoff, H., and Peter, R. E. (1999). Actions of two forms of gonadotropin releasing hormone and a $\mathrm{GnRH}$ antagonist on spawning behavior of the goldfish Carassius auratus. Gen. Comp. Endocrinol. 116, 347-355.

White, R. B., Eisen, J. A., Kasten, T. L. and Fernald, R. D. (1998). Second gene for gonadotropin-releasing hormone in humans. Proc. Natl. Acad. Sci. U.S.A. 95, 305-309.
White, S. A., Nguyen, T., and Fernald, R. D. (2002). Social regulation of gonadotropin-releasing hormone. J. Exp. Biol. 205, 25672581.

Yang, Y., Zhou, L. B., Liu, S., Tang, J. F., Li, F. Y., Li, R. Y., et al. (2005). Expression of feedingrelated peptide receptors mRNA in GT1-7 cell line and roles of leptin and orexins in control of GnRH secretion. Acta Pharmacol. Sin. 26, 976-981.

Yokobori, E., Azuma, M., Nishiguchi, R., Kang, K. S., Uchiyama, M., and Matsuda, K. (2012). Neuropeptide Y stimulates food intake in the zebrafish, Danio rerio. J. Neuroendocrinol. 24, 766-773.
Yokobori, E., Kojima, K., Azuma, M., Kang, K. S., Maejima, S., Uchiyama, M., et al. (2011). Stimulatory effect of intracerebroventricular administration of orexin A on food intake in the zebrafish, Danio rerio. Peptides 32 , 1357-1362.

Conflict of Interest Statement: The authors declare that the research was conducted in the absence of any commercial or financial relationships that could be construed as a potential conflict of interest.

Received: 31 August 2012; paper pending published: 24 September 2012; accepted: 30 September 2012; published online: 17 October 2012.
Citation: Nishiguchi R, Azuma M, Yokobori E, Uchiyama $M$ and Matsuda $K$ (2012) Gonadotropin-releasing hormone 2 suppresses food intake in the zebrafish, Danio rerio. Front. Endocrin. 3:122. doi: 10.3389/fendo.2012.00122

This article was submitted to Frontiers in Neuroendocrine Science, a specialty of Frontiers in Endocrinology.

Copyright (c) 2012 Nishiguchi, Azuma, Yokobori, Uchiyama and Matsuda. This is an open-access article distributed under the terms of the Creative Commons Attribution License, which permits use, distribution and reproduction in other forums, provided the original authors and source are credited and subject to any copyright notices concerning any thirdparty graphics etc. 